Jurnal Ilmiah "Kreatif" Vol. XII No. 2 Juli 2015

"Jurnal Studi Pemikiran Pendidikan Agama Islam"

\title{
MENJADI PENDIDIK YANG BERMUTU
}

\author{
Oleh: Irwan
}

\begin{abstract}
Abstrak:
Pendidik atau biasa disebut dengan guru merupakan salah satu faktor yang sangat penting dalam dunia pendidikan yang harus mendapatkan perhatian khusus dalam peningkatan kualitas atau mutunya, karena bagaimana dapat menghasilkan peserta didik yang bermutu jika pendidiknya tidak bermutu. Hal tersebut juga dikarenakan pendidik (guru) adalah orang pertama yang selalu mendapatkan sorotan dari masyarakat. Ketika terjadi terjadi berbagai hal tentang peserta didik, baik peserta didik tersebut berkelakuan baik terlebih lagi berkelakuan buruk, maka gurunya lah yang pertama kali menjadi sorotan, lebih-lebih guru Agama. Meskipun upaya meningkatkan kualitas guru baik ditingkat institusi (lembaga pendidikan) maupun secara umum selalu dilakukan mulai dari pelaksanaan pendidikan dan pelatihan guru, pemberian tunjangan yang langsung dianggarkan dari APBN, kenaikan gaji guru terutama PNS, sampai pada program sertifikasi guru, kenyataannya ini belum bisa memberikan bukti nyata perubahan dalam pendidikan di Indonesia. Pendidikan dan pelatihan guru menguap bagai air, tunjangan dan kenaikan gaji bagai karpet terbang yang membawa mereka keawan, dan sertifikasi merupakan pesawat ulang alik yang membawa mereka ke luar angkasa yang bebas bergerak tanpa perlu berpijak. Perbaikan fasilitas yang diberikan pemerintah tidak mengubah keadaan pendidikan di Indonesia. Hanya sedikit tenaga pendidik yang memang menjadikan perbaikan fasilitas tersebut sebagai alat untuk mengadakan perubahan signifikan dalam dunia pendidikan, tetapi persentasinya sangat kecil bila dibandingkan dengan jumlah pendidik dan siswa sekolah yang ada di Indonesia.
\end{abstract}

Kata Kunci: Pendidik, Mutu, Lembaga Pendidikan Islam

\section{Pendahuluan}

Pendidikan di dunia saat ini, khususnya di dunia Islam mengalami krisis yang menyebabkan kemunduran. Para pemerhati pendidikan telah menganalisis beberapa sebab terjadinya kemunduran itu, di antaranya adalah karena ketidaklengkapan aspek materi, terjadinya krisis sosial masyarakat dan krisis budaya, serta hilangnya

*Penulis adalah Dosen Tetap STAI Muhammadiyah Bima 
Jurnal Ilmiah "Kreatif" Vol. XII No. 2 Juli 2015

"Jurnal Studi Pemikiran Pendidikan Agama Islam"

qudwah hasanah (teladan yang baik), akidah shahihah, dan nilai-nilai Islami. Ada juga yang melihat penyebabnya adalah karena salah memahami eksistensi manusia, sehingga salah pula melihat eksistensi anak didik. $^{1}$

Krisis pendidikan yang terjadi di dunia Islam ini juga dialami oleh Indonesai. Masalah yang dihadapi pun cukup beragam. Mulai dari aspek sosial, politik, budaya dan ekonomi, serta aspek lainnya. Sebagai contoh, akhir-akhir ini banyak orang mulai gelisah terhadap kebobrokan perilaku kehidupan masyarakat bangsa ini. Para elitnya banyak yang korup. Tidak kurang dari 17 Gubernur menjadi tersangka kasus korupsi bahkan sudah banyak yang divonis. ${ }^{2}$ Lebih dari 150 orang bupati dan walikota terkena kasus yang sama, yaitu menggelapkan uang Negara. Belum lagi mantan menteri, jaksa, hakim, pimpinan BUMN, dan bahkan unsur KPK sendiri, ternyata masuk bui. Seolah-olah tidak ada yang tersisa dan bertahan dengan nilai kejujuran serta integritas yang memadai.

Pendidikan Nasional yang disusun pemerintah melalui undang-undang sebenarnya sudah menekankan pentingnya pembangunan karakter anak didik. Hal ini terimplikasi melalui pendidikan akhlak dalam hal pembinaan moral dan budi pekerti (sesuai UU Sisdiknas tahun 1989 atau revisinya tahun 2003). Disebutkan dalam UU Sisdiknas Pasal 3 UU No. 20/2003 bahwa tujuan pendidikan nasional adalah untuk melahirkan manusia yang beriman dan bertakwa dan dalam pasal 36 tentang Kurikulum dikatakan, kurikulum disusun dengan memperhatikan peningkatan iman dan takwa. Meskipun dalam pasal-pasal tersebut kata-kata "iman dan takwa" tidak terlalu dijelaskan, namun kenyataannya dapat dikatakan bahwa mayoritas akhlak para peserta didik yang dihasilkan dari proses pendidikan di Indonesia tidak sesuai dengan yang dirumuskan. ${ }^{3}$

Dipahami bahwa proses pembangunan sebuah bangsa pada hakikatnya diarahkan untuk membangun manusia seutuhnya, baik moral maupun material. Membangun manusia yang berakhlak atau bermoral berarti membangun kualitas bangsa. John Gardner, mengatakan bahwa suatu bangsa akan menjadi besar apabila bangsa itu percaya pada

1 Zaglul al-Najar, Nadzarat fi Azmat al-Ta'lim al-Mu'ashir wa Hululiha alIslamiyah (Cairo: Maktabah Wahbah, 1427 H/2006), 24-26.

2 Imam Suprayogo, Pengembangan Pendidikan Karakter (Malang: UIN Maliki Press, 2013), ix.

${ }^{3}$ Menurut UU Sisdiknas Pasal 4 UU No. 2/1989. Lihat Ahmad Tafsir, "Kajin Pendidikan Islam di Indonesia", dalam Tedi Priatna (ed), Cakrawala Pemikiran Pendidikan Islam (Bandung: Mimbar Pustaka, 2004), 23. 
Jurnal Ilmiah "Kreatif" Vol. XII No. 2 Juli 2015

"Jurnal Studi Pemikiran Pendidikan Agama Islam"

sesuatu, dan sesuatu itu harus berdimensi moral, sesuatu yang berdimensi moral tidak lain bersumber dari ajaran agama. ${ }^{4}$

Agama akan membentuk manusia bermoral apabila dilakukan melalui jalur proses pendidikan. Mastuhu dalam A. Fatah Yasin juga berpendapat bahwa manusia adalah mahluk yang memiliki daya akal dan kehidupan, maka ia harus membentuk peradaban dan memajukan kehidupan melalui proses pendidikan (belajar mengajar). ${ }^{5}$ Untuk mewujudkan pendidik yang bermutu, diperlukan pendidik yang bermoral dan berakhlak mulia, oleh karena itu diperlukan lembaga pendidikan yang seluruh komponennya secara intens melakukan kegiatan memahamkan, menanamkan dan membiasakan serta membentuk manusia (peserta didik) dengan moral dan akhlak karimah. Salah satu komponen yang memegang peranan penting dalam dunia pendidikan adalah pendidik.

Adapun lembaga pendidikan Islam secara terminologi dapat diartikan suatu wadah atau tempat berlangsungnya proses pendidikan Islam. Dari definisi di atas dapat disimpulkan bahwa lembaga pendidikan itu mengandung pengertian kongkrit berupa sarana dan prasarana dan juga pengertian yang abstrak, dengan adanya normanorma dan peraturan-peraturan tertentu, serta penananggung jawab pendidikan itu sendiri. Selain itu, lembaga pendidikan Islam adalah suatu bentuk wadah organisasi yang dapat digunakan atau berfungsi sebagai pengembangan kegiatan pendidikan Islam. ${ }^{6}$

Lembaga Pendidikan Islam muncul dari pemikiran-pemikiran yang selaras dengan kebutuhan masyarakat, tuntutan perkembangan Zaman, didasari, digerakkan dan dikembangkan berdasarkarkan alQur'an dan Sunah. Karena itu Lembaga Pendidikan Islam tumbuh dan berkembang seiring dengan pertumbuhan dan perkembangan ajaran Islam itu sendiri. Lembaga Pendidikan Islam dikenal sejak detik-detik awal turunnya wahyu kepada Nabi Muhammad SAW. Rumah Al-Arqam merupakan lembaga pendidikan yang pertama, kemudian berkembang dengan istilah Kuttab (pesantren), Masjid, Saloon, Madrasah dan Sekolah.

Sesuai dengan jalur pendidikan yang telah ditetapkan pemerintah bahwa pendidikan agama Islam berbentuk pendidikan diniyah dan pesantren yang diselenggarakan dengan jalur Formal,

\footnotetext{
${ }^{4}$ Nurcholish Madjid, Islam, Doktrin dan Peradaban (Jakarta: Yayasan Wakaf Paramadina, 1993), xx.

${ }^{5}$ A. Fatah Yasin, Pengembangan Sumberdaya Manusia di Lembaga Pendidikan Islam, (Malang: UIN Maliki Press, 2011), hlm. 3.

${ }^{6}$ Ibid, 201
} 
Jurnal Ilmiah "Kreatif" Vol. XII No. 2 Juli 2015

"Jurnal Studi Pemikiran Pendidikan Agama Islam"

Nonformal, dan Informal. Oleh karena itu, lembaga pendidikan Islam terbagi menjadi tiga jenis, yaitu: lembaga pendidikan Islam formal, lembaga pendidikan Islam nonformal dan lembaga pendidikan Islam informal.

\section{Pengertian Pendidik dalam Pendidikan Islam dan Pendidikan Nasional}

Pendidik dalam Islam ialah siapa saja yang bertanggung-jawab terhadap perkembangan anak didik. Dalam Islam, orang yang paling bertanggung-jawab adalah orangtua (ayah dan ibu) anak didik. Tanggung jawab itu disebabkan oleh dua hal yaitu pertama, karena kodrat yaitu karena orangtua ditakdirkan menjadi orangtua anaknya, dan karena itu ia ditakdirkan pula bertanggung-jawab mendidik anaknya. Kedua, karena kepentingan kedua orangtua yaitu orangtua berkepentingan terhadap kemajuan perkembangan anaknya.

Dalam kamus besar Bahasa Indonesia dinyatakan, bahwa pendidik adalah orang yang mendidik. ${ }^{7}$ Dalam pengertian yang lazim digunakan, pendidik adalah orang dewasa yang bertanggung jawab memberikan pertolongan pada paserta didiknya dalam perkembangan jasmani dan rohaninya, agar mencapai tingkat kedewasaan, mampu mandiri dalam memenuhi tugasnya sebagai hamba dan khalifah Allah swt dan mampu melakukan tugas sebagai makhluk sosial dan sebagai makhluk individu yang mandiri. ${ }^{8}$

Istilah pendidik mencakup pula guru, dosen, dan guru besar. Guru adalah pendidik professional dengan tugas utama mendidik, mengajar, membimbing, mengarahkan, melatih, menilai, dan mengevaluasi peserta didik pada pendidikan anak usia dini jalur pendidikan formal, pendidikan dasar dan pendidikan menengah. Dosen adalah pendidik profesional dan ilmuan dengan tugas utama mentransformasikan, mengembangkan, dan menyebarluaskan ilmu pengetahuan, teknologi dan seni melalui pendidikan, penelitian, dan pengabdian kepada masyarakat. Sedangkan guru besar atau professor adalah jabatan fungsional tertinggi bagi dosen yang masih mengajar di lingkungan satuan pendidikan tinggi. ${ }^{9}$

Dalam literatur kependidikan Islam, banyak istilah yang dipakai untuk menyebut seorang guru seperti ustadz, mu'allim,

${ }^{7}$ W.J.S. Perwadarmita, Kamus Umum Bahasa Indonesia (Jakarta: Balai Pustaka, 1991), 250

${ }^{8}$ Abuddin Nata, Ilmu Pendidikan Islam (Jakarta: Kencana, 2010), hlm. 159

${ }^{9}$ Ibid., 159. 
Jurnal Ilmiah "Kreatif" Vol. XII No. 2 Juli 2015

"Jurnal Studi Pemikiran Pendidikan Agama Islam"

murabbiy, mursyid, mudarris, dan mu'addib. ${ }^{10}$ Semua istilah tersebut secara umum memiliki makna yag sama.

Dari hasil telaah terhadap literatur pendidikan Islam, Muhaimin mengemukakan bahwa masing-masing istilah tersebut merupakan fungsi dan karaktersitik guru yang kemudian menjadi penyebutannya. Untuk lebih jelasnya, diuraikan sebgai berikut:

a. Ustadz adalah orang yang berkomitmen terhadap profesionalitas, yang melekat pada dirinya adalah sikap dedikatif, komitmen terhadap mutu proses dan hasil kerja, serta sikap continuous improvement.

b. Mu'allim adalah orang yang menguasai ilmu dan mampu mengembangkannya serta menjelaskan fungsinya dalam kehidupan, menjelaskan dimensi teoritis dan praktisnya.

c. Murabby adalah orang yang mendidik dan menyiapkan peserta didik agar mampu berkreasi, serta mampu mengatur dan memelihara hasil kreasinya untuk tidak menimbulkan malapetaka bagi dirinya, masyarakat, dan alam sekitarnya.

d. Mursyid adalah orang yang mampu menjadi model atau sentral identifikasi diri, atau menjadi pusat panutan, teladan, dan konsultan bagi peserta didiknya.

e. Mudarris adalah orang yang memiliki kepekaan intelektual dan informasi, serta memperbaharui pengetahuan dan keahliannya secara berkelajutan, dan berusaha mencerdaskan peserta didiknya.

f. Mu'addib adalah orang yang mampu menyiapkan peserta didik untuk bertanggung jawab dalam membangun peradaban yang berkualitas di masa depan. ${ }^{11}$

Dalam Undang-Undang tentang Guru dan Dosen Tahun 2005 dijelaskan pada pasal 1 ayat 1 bahwa "Guru adalah pendidik profesional dengan tugas utama mendidik, mengajar, membimbing, mengarahkan, melatih, menilai, dan mengevaluasi peserta didik pada jalur pendidikan formal, serta pada jenjang pendidikan dasar dan pendidikan menengah, termasuk pendidikan anak usia dini." 12

Untuk melaksanakan tugas tersebut, maka seorang guru harus memiliki kamampuan dan kompetensi yang terkait dengan profesinya sebagai seorang guru. Dalam Undang-Undang Guru dan Dosen telah

${ }^{10}$ Muhaimin, Pengembangan Kurikulum Pendidikan Agama Islam di Sekolah, Madrasah, dan Perguruan Tinggi (Jakarta: RajaGrafindo Persada, 2005), 44.

${ }^{11}$ Ibid, hlm. 50.

${ }^{12}$ Undang-Undang SISDIKNAS No. 20 Tahun 2003, PP RI No. 47 Tahun 2008, UU Guru dan Dosen Tahun 2005, 77 
Jurnal Ilmiah "Kreatif" Vol. XII No. 2 Juli 2015

"Jurnal Studi Pemikiran Pendidikan Agama Islam"

dijelaskan bahwa seseorang yang ingin menjadi guru atau pendidik, maka ia harus memiliki standar kualifikasi akademik dan standar kompetensi.

Istilah kompetensi guru mempunyai banyak makna, Broke and Stone dalam bukunya E Mulyasa mengemukakan bahwa kompetensi guru merupakan gambaran kualitatif tentang hakikat perilaku guru yang penuh arti. ${ }^{13}$ Sedangkan dalam PP RI No 19 Tahun 2005 tentang Standar Nasional Pendidikan, bab VI pasal 28 ayat (3) disebutkan bahwa kompetensi sebagai agen pembelajaran pada jenjang pendidikan dasar dan menengah serta pendidikan anak usia dini meliputi: kompetensi pedagogik, kompetensi kepribadian, kompetensi professional, dan kompetensi sosial. ${ }^{14}$

\section{Standar Mutu Guru di Lembaga Pendidikan Islam}

Mutu adalah gambaran dan karakteristik menyeluruh dari barang atau jasa yang menunjukkan kemampuannya dalam memuaskan kebutuhan yang ditentukan oleh pelanggan. ${ }^{15}$ Dalam konteks pendidikan, pengertian mutu dapat dilihat mulai dari input, proses, dan output. Kualitas atau mutu adalah conformance to requirement yaitu sesuai yang diisyaratkan atau distandarkan. Suatu produk memiliki kualitas apabila sesuai dengan standar kualitas yang telah ditentukan. Standar kualitas meliputi bahan baku, proses produksi, dan produksi jadi. ${ }^{16}$

Kualitas adalah "doing the right thing, right time, always striving for improvement, and always satisfying the customers". Selain itu kualitas merupakan suatu kondisi dinamis yang berhubungan dengan produk, jasa, manusia, proses, dan lingkungan yang memenuhi atau melebihi harapan. ${ }^{17}$ Kualitas atau mutu apabila diaplikasikan ke dalam dunia pendidikan sebagai berikut:

a. Kualitas mencakup usaha memenuhi atau melebihi harapan pelanggan

b. Kualitas mencakup produk, jasa manusia, proses, dan lingkungan

c. Kualitas merupakan kondisi yang selalu berubah (misalnya apa yang dianggap merupakan kualitas saat ini mungkin dianggap kurang berkualitas pada masa mendatang).

${ }^{13}$ E. Mulyasa, Standar Kompetensi dan Sertifikasi Guru (Bandung: Remaja Rosdakarya, 2007), 25

${ }^{14}$ Undang-Undang Sisdiknas No. 20 Tahun 2003,...77.

15 Edward Sallis, Total Quality Management in Education (Jogjakarta: IRCiSoD, 2010), 56

${ }_{16}$ Philip B. Crosby, Quality is Free (Mc-Graw Hill Book, New York, 1979), 58

${ }^{17}$ Fandy Tjiptono dan Anastasia Diana, Total Quality Management (TQM) (Yogyakarta: Penerbit Andi Offset, 1998), 120 
Jurnal Ilmiah "Kreatif" Vol. XII No. 2 Juli 2015

"Jurnal Studi Pemikiran Pendidikan Agama Islam"

Dalam manajemen mutu terpadu makna kualitas atau mutu adalah suatu filosofi komprehensif tentang kehidupan dan kegiatan lembaga yang menekankan perbaikan berkelanjutan tujuan fundamental untuk meningkatkan mutu, produktivitas, dan mengurangi pembiayaan. ${ }^{18}$

Dari uraian tentang mutu di atas, maka mutu pendidik merupakan kualitas sesuai dengan standar yang telah ditentukan oleh pelanggan, baik pelanggan internal maupun eksternal. Dalam PP no. 19 Tahun 2005 tentang Standar Nasional Pendidikan bab VI disebutkan bahwa Pendidik secara umum harus memiliki kualifikasi akademik dan kompetensi sebagai agen pembelajaran, sehat jasmani dan rohani, serta memiliki kemampuan untuk mewujudkan tujuan pendidikan nasional. ${ }^{19}$

\section{a. Standar kualifikasi}

Pendidikan mutu guru sebagai pendidik dan tenaga kependikan dilaksanakan dengan mengacu pada standar pendidik dan tenaga kependidikan mata pelajaran dalam Standar Nasional Pendidikan (SNP). Untuk itu dilakukan kegiatan-kegiatan penyediaan guru pendidikan agama Islam untuk satuan pendidikan peserta didik usia dini, pendidikan dasar, pendidikan menengah, dan pendidikan tinggi pada jalur formal dan non formal, serta informal. Dilakukan pula pendidikan dan pelatihan metode pembelajaran, pemberian beasiswa peserta didik Strata 1 (S1) untuk guru, dan juga melakukan sertifikasi guru bidang studi. ${ }^{20}$

Dalam manajemen mutu perbaikan terus menerus merupakan suatu keharusan. ${ }^{21}$ Artinya semua komponen yang terlibat dalam sebuah organisasi termasuk guru harus senantiasa melihat segala kekurangannya dan tetap melakukan perbaikan demi tercapainya tujuan yang telah ditentukan bersama.

\section{b. Standar Kompetensi Pendidik}

Istilah kompetensi guru mempunyai banyak makna, Broke and Stone mengemukakan bahwa kompetensi guru merupakan gambaran kualitatif tentang hakikat perilaku guru yang penuh arti. ${ }^{22}$

Sedangkan dalam PP RI No 19 Tahun 2005 tentang Standar Nasional Pendidikan, bab VI pasal 28 ayat (3) disebutkan bahwa

\footnotetext{
18 Syafauddin, Manajemen Mutu Terpadu dalam Pendidikan: Konsep, Strategi, dan Aplikasi (Jakarta: Grasindo, 2002), 29

${ }^{19}$ Undang-Undang SISDIKNAS No. 20 Tahun 2003..., 77.

${ }^{20} \mathrm{http}$ ///idhammaulana.blogspot.com/ "Pendidikan Agama Islam di Sekolah" diakses Jumat, 29 April 2014.

${ }^{21}$ Edward Sallis, Total Quality Management..., hlm. 76.

${ }^{22}$ E. Mulyasa, Standar Kompetensi dan Sertifikasi Guru (Bandung: Remaja Rosdakarya, 2007), 25.
} 
Jurnal Ilmiah "Kreatif" Vol. XII No. 2 Juli 2015

"Jurnal Studi Pemikiran Pendidikan Agama Islam"

kompetensi sebagai agen pembelajaran pada jenjang pendidikan dasar dan menengah serta pendidikan anak usia dini meliputi: kompetensi pedagogik, kompetensi kepribadian, kompetensi professional, dan kompetensi sosial. ${ }^{23}$

\section{Pendidik yang Bermutu}

Guru merupakan figur sentral dalam proses pendidikan yang berlangsung di sekolah. Karena itu, profesionalisme dan kualitas guru merupakan faktor yang dominan dalam upaya meningkatkan kualitas pendidikan. Dari sudut pandang nilai budaya Indonesia (Sunda), guru profesional adalah seorang pendidik yang memiliki "komara" atau willpower atau determinasi (strength of will, strength of mind, self control, dan self discipline) yang sangat tinggi, sehingga dipatuhi (digugu) perkataannya dan diikuti (ditiru) perilakunya. ${ }^{24}$

Dua kemampuan (ability) mendasar yang harus dimiliki guru pada era globalisasi dewasa ini. Pertama, kemampuan memanfaatkan teknologi sebagai media dan sumber pembelajaran. Misalnya penguasaan berbagai program aplikasi komputer dan internet untuk pembelajaran. Kedua, kemampuan mentransfer nilai-nilai kehidupan (living values) kepada semua peserta didik. Dalam hal ini guru harus mengembangkan dan mempromosikan soft skill bagi peserta didik, yang meliputi nilai-nilai: kejujuran, penghargaan, sikap toleran, kemampuan mendengar, empati, kerja sama, sopan santun dalam berperilaku, disiplin, dan kontrol diri. ${ }^{25}$

Menurut E Mulyasa, tugas guru dalam pembelajaran tidak terbatas sekedar penyampaian informasi (transfer of information), tetapi sesuai dengan kemajuan dan tuntutan zaman, guru harus memiliki kemampuan untuk memahami peserta didik dengan berbagai keunikannya, sehingga mampu membantu mengatasi kesulitan peserta didik. ${ }^{26}$ Sedangkan Amir Tengku Ramly mengatakan bahwa guru harus memahami perilaku belajar peserta didik secara personal. Perilaku belajar peserta didik

\footnotetext{
${ }^{23}$ Undang-Undang Sisdiknas, No.20 Tahun 2003..., 77

${ }^{24}$ Dodi Nandika, Pendidikan di Tengah Perubahan (Jakarta : Pustaka LP3ES Indonesia, 2007), cet. ke-1, 62

${ }^{25}$ Deni Koswara dan Halimah, Seluk Beluk Profesi Guru (Bandung: Pribumi Mekar, 2008), cet. ke-1, 135.

${ }^{26}$ E Mulyasa, Menjadi Guru Profesional Menciptakan Pembelajaran Kreatif dan Menyenangkan (Bandung: Remaja Rosdakarya, 2011), cet. ke-10, 21.
} 
Jurnal Ilmiah "Kreatif" Vol. XII No. 2 Juli 2015

"Jurnal Studi Pemikiran Pendidikan Agama Islam"

tersebut secara garis besar dikelompokkan pada empat kategori, yaitu sanguinis, phlegmatis, melankolis, dan korelis. ${ }^{27}$

Pemahaman terhadap perilaku belajar peserta didik akan memberikan kekuatan tersendiri bagi guru dan kesan yang mendalam bagi peserta didik. Sehingga pembelajaran dirasakan penuh makna (meaning full learning) dan menyenangkan. Pembelajaran yang menyenangkan akan memberikan dampak terhadap perubahan perilaku peserta didik. Hal ini didasarkan pada teori Skinner yang menyebutkan bahwa perilaku berubah sesuai dengan konsekuensi-konsekuensi langsung dari perilaku tersebut. Konsekuensi yang menyenangkan akan memperkuat perilaku, sedangkan konsekuensi yang tidak menyenangkan akan memperlemah perilaku. ${ }^{28}$

Selain hal di atas, ada beberapa hal yang harus selalu diupayakan oleh guru, yaitu:

1. Menjadi Guru Teladan

Guru harus menjadi teladan bagi peserta didiknya dalam segala perkataan, perbuatan dan prilaku. Guru harus selalu jujur, adil, berkata yang baik, dan memberi nasihat serta pengarahan kepada anak didik. Ada beberapa langkah jitu agar menjadi sosok guru teladan di mata para peserta didik, diantaranya adalah; Jangan hanya mendidik dengan kata-kata, namun yang lebih utama adalah contoh sikap dari sang guru. Guru adalah contoh teladan. Contoh yang paling efektif adalah contoh sikap, bukan hanya bicara. Guru akan sangat dinilai dari sikap prilakunya oleh para siswa. Jika ingin para siswa suka pada Anda, perbaiki lah sikap-sikap buruk Anda.

Menjaga tutur kata dan bahasa. Mendidik lah dengan kelembutan dan kebijaksanaan. Bukan kebengisan maupun kediktatoran. Manakah yang lebih Anda sukai antara ditakuti dan disegani? Disegani lebih terhormat dari pada ditakuti. Segan bisa muncul sebagai dampak dari kebijaksanaan sikap-sikap Anda. Namun takut merupakan efek dari prilaku sebaliknya.

2. Jadilah guru yang berprestasi.

Jika Anda seorang pendidik, usahakan Anda memiliki prestasi yang lebih baik dan dapat dibanggakan terhadap hal yang Anda ajarkan. Misalkan Anda seorang guru seni atau olah raga, maka Anda juga dituntut memiliki prestasi yang baik di dunia seni dan olah raga.

${ }^{27}$ Amir Tengku Ramly, Menjadi Guru Idola Mengajar dari Kedalaman Cinta (Bekasi: Pustaka Inti, 2007), cet. ke-3, 68.

${ }^{28}$ Trianto, Mendesain Model Pembelajaran Inovatif-Progresif (Jakarta: Prenada Media Group, 2010), cet. ke-2, 39-40. 
Jurnal Ilmiah "Kreatif" Vol. XII No. 2 Juli 2015

"Jurnal Studi Pemikiran Pendidikan Agama Islam"

3. Jadilah Guru yang Profesional

Diantara cirri dari guru yang profesional adalah menguasai materi pelajaran dengan matang melebihi peserta didik dan mampu memberikan pemahaman kepada mereka secara baik. Guru harus memiliki kesiapan alami (fitrah) untuk menjalani proses mengajar, seperti pemikiran yang lurus, bashirah yang jernih, tidak melamun, berpandangan jauh ke depan, cepat tanggap, dan dapat mengambil tindakan yang tepat pada saat-saat kritis.

Guru harus menguasai cara-cara mengajar dan menjelaskan, mesti menelaah buku-buku yang berkaitan dengan bidang studi yang diajarkan. Sebelum memasuki pelajaran, guru harus siap secara mental, fisik, waktu dan ilmu (materi). Maksud kesiapan mental dan fisik adalah tidak mengisi pelajaran dalam keadaan perasaan yang kacau, malas ataupun lapar. Kesiapan waktu adalah dia mengisi pelajaran itu dengan jiwa yang tenang, tidak menghitung tiap detik yang berlalu, tidak menanti-nanti waktu usainya atau menginginkan para siswa membaca sendiri tanpa diterangkan maksudnya, atau menghabiskan jam pelajaran dengan hal-hal yang tidak ada gunanya bagi siswa. Sedangkan maksud kesiapan ilmu adalah dia menyiapkan materi pelajaran sebelum masuk kelas. Dia menyiapkan apa yang dikatakannya. Sebiasa mungkin, dia menghindari spontanitas dalam mengajar jika tidak menguasai materinya.

4. Menjadi Guru yang Efektif

Guru yang efektif adalah guru yang biasa memotivasi peserta didik untuk belajar dan meningkatkan semangat belajar yang tumbuh dari kesadaran diri peserta didik, bukan karena takut pada gurunya. Ada beberapa ciri guru efektif, diantaranya:

$\checkmark$ Berpikir, bertutur, dan berbuat secara positif.

$\checkmark$ Berkomunikasi dengan minat dan antusias.

$\checkmark$ Perhatian terhadap peserta didik yang diajak bicara.

$\checkmark$ Mengungkapkan pertanyaan, arahan, dan pernyataan dengan jelas.

$\checkmark$ Menggunakan berbagai metode pengajaran.

$\checkmark$ Memanfaatkan humor agar suasana kelas menarik.

$\checkmark$ Tenang dalam menghadapi masalah.

$\checkmark$ Menghidari perilaku marah yang berlebihan.

5. Menjadi Guru yang Ikhlas

Guru yang ikhlas ialah guru yang setiap harinya selalu berdedikasi untuk mencerdaskan kehidupan bangsa tanpa pamrih. Guru yang tidak terlalu terganggu dengan besar kecinya gaji, guru yang tidak terlalu menuntut fasilitas lebih 
Jurnal Ilmiah "Kreatif" Vol. XII No. 2 Juli 2015

"Jurnal Studi Pemikiran Pendidikan Agama Islam"

karena dalam benaknya semua yang ada disekitarnya merupakan fasilitas bagi pengajarannya. Guru dengan tipe ini selalu memperhatikan perkembangan siswanya, sehingga setiap perbuatan yang dilakukannya selalu didasari pertanyaan "dapatkah siswa saya melaksanakannya? apakah yang saya ajarkan sudah sesuai tujuan yang diinginkan (tujuan materi dan tujuan pendidikan).?"

\section{Strategi Peningkatan Mutu Pendidik}

Sudahkah pendidik di negeri ini menjadi sosok yang ideal dan bermutu bagi murid-muridnya? Secara kasat mata sepertinya belum, masih banyak kelemahan dan kekurangan guru di negeri ini, baik aspek intelektualitas, moralitas, maupun dedikasi sosialnya. ${ }^{29}$ Oleh karena itu peningkatan kualitas guru adalah salah satu kunci memajukan pendidikan yang ditunggu-tunggu oleh anak didik dan masyarakat secara umum. Berbagai program harus diadakan untuk menunjang pengembangan potensi guru ini. Disisi lain guru juga harus termotivasi untuk banyak membaca, berlatih berkarya, serta menjadi figur inspirator dan motivator bagi anak didik dan masyarakat.

Tanpa daya keinginan dalam diri guru, maka usaha apapun yang dilakukan oleh pemerintah tidak ada artinya, karena hanya formalitas belaka, tanpa ada energy perubahan ke arah yang lebih baik sesuai dengan harapan yang diinginkan semua pihak. Hanya sekadar mengikuti pelatihan tanpa ada efeknya. ${ }^{30}$

Tenaga pendidik yang bermutu merupakan dambaan bagi semua lapisan masyarakat, banyak strategi yang dilakukan oleh perorangan guru dan lembaga untuk meningkatkan mutu guru, seperti: (1) melalui peningkatan jenjang akademik, (2) workshop, (3) penataran, (4) peningkatan kinerja, (5) studi banding, dan lain sebagainya. Penambahan pengetahuan dan pengalaman dapat mengangkat mutu tenaga pedidik, artinya mereka harus selalu mengembangkan kapasitas dirinya selalu berusaha untuk menjadi panutan atau contoh teladan yang baik, selain itu, hal yag terpenting juga adalah guru harus harus mampu medesain pembelajaran yang bermutu serta memiliki konsep hidup "melakukan perbaikan secara terus menerus".

29 Jamal ma'mur Asmani, Manajemen Pengelolaan Dan Kepemimpinan Pendidikan Professional (Jogjakarta: DIVA Press, 2009), 58.

${ }^{30}$ Ibid, 59. 
Jurnal Ilmiah "Kreatif" Vol. XII No. 2 Juli 2015

"Jurnal Studi Pemikiran Pendidikan Agama Islam"

\section{Simpulan}

Peningkatan mutu dunia pendidikan pada berbagai aspeknya saat ini sudah menjadi harga mati yang memang harus menjadi perioritas utama bangsa ini. Hal ini merupakan sebuah konsekwensi yang harus segera direalisasikan agar output (generasi) yang dihasilkan dari dunia pendidikan di tanah air ini menjadi generasi yang bermutu, yaitu generasi yang akan mampu melanjutkan pembangunan bangsa ini di segala bidang bukan sebaliknya yaitu menghasilkan generasi yang akan menghambat berbagai macam pembangunan di tanah air tercinta ini.

Dari berbagai hal yang dikemukakan di atas, Pendidik atau biasa disebut dengan guru, dosen dan lain sebagainya merupakan salah satu faktor yang sangat penting dalam dunia pendidikan yang harus mendapatkan perhatian khusus dalam peningkatan kualitas atau mutunya, karena bagaimana dapat menghasilkan peserta didik yang bermutu jika pendidiknya tidak bermutu. Hal tersebut juga dikarenakan pendidik (guru) adalah orang pertama yang selalu mendapatkan sorotan dari masyarkat. Ketika terjadi terjadi berbagai hal tentang peserta didik, baik peserta didik tersebut berkelakuan baik terlebih lagi berkelakuan buruk, maka gurunya lah yang pertama kali menjadi sorotan, lebih-lebih guru Agama.

Untuk merealisasikan peningkatan mutu pendidik di tanah air tercinta ini, maka diharapkan keikhlasan dan kemauan yang kuat dalam diri pribadi masing-masing pendidik untuk meningkatkan mutu, karena bagaimanapun program yang dilaksanakan oleh pemerintah, instansi atau lembaga pendidikan dalam rangka peningkatan mutu pendidik akan menjadi hambar dan tidak ada manfaatnya jika tidak ada kerjasama dari para pendidik.

\section{Daftar Pustaka}

Zaglul al-Najar, Nadzarat fi Azmat al-Ta'lim al-Mu'ashir wa Hululiha al-Islamiyah, Kairo: Maktabah Wahbah, 1427 H/2006.

Imam Suprayogo, Pengembangan Pendidikan Karakter, Malang: UIN Maliki Press, 2013.

Tedi Priatna (ed), Cakrawala Pemikiran Pendidikan Islam, Bandung: Mimbar Pustaka, 2004.

Nurcholish Madjid, Islam, Doktrin dan Peradaban, Jakarta: Yayasan Wakaf Paramadina, 1993.

A. Fatah Yasin, Pengembangan Sumberdaya Manusia di Lembaga Pendidikan Islam, Malang: UIN Maliki Press, 2011. 
Jurnal IImiah "Kreatif" Vol. XII No. 2 Juli 2015

"Jurnal Studi Pemikiran Pendidikan Agama Islam"

W.J.S. Perwadarmita, Kamus Umum Bahasa Indonesia, Jakarta: Balai Pustaka, 1991.

Abuddin Nata, Ilmu Pendidikan Islam, Jakarta: Kencana, 2010.

Muhaimin, Pengembangan Kurikulum Pendidikan Agama Islam di Sekolah, Madrasah, dan Perguruan Tinggi, Jakarta: RajaGrafindo Persada, 2005.

E. Mulyasa, Standar Kompetensi dan Sertifikasi Guru, Bandung: Remaja Rosdakarya, 2007.

Edward Sallis, Total Quality Management in Education, Jogjakarta: IRCiSoD, 2010.

Philip B. Crosby, Quality is Free, Mc-Graw Hill Book, New York, 1979.

Fandy Tjiptono dan Anastasia Diana, Total Quality Management (TQM), Yogyakarta: Penerbit Andi Offset, 1998.

Syafauddin, Manajemen Mutu Terpadu dalam Pendidikan: Konsep, Strategi, dan Aplikasi, Jakarta: Grasindo, 2002.

Dodi Nandika, Pendidikan di Tengah Perubahan, Jakarta : Pustaka LP3ES Indonesia, 2007.

Deni Koswara dan Halimah, Seluk Beluk Profesi Guru, Bandung: Pribumi Mekar, 2008.

E Mulyasa, Menjadi Guru Profesional Menciptakan Pembelajaran Kreatif dan Menyenangkan, Bandung: Remaja Rosdakarya, 2011.

Amir Tengku Ramly, Menjadi Guru Idola Mengajar dari Kedalaman Cinta, Bekasi: Pustaka Inti, 2007.

Trianto, Mendesain Model Pembelajaran Inovatif-Progresif, Jakarta: Prenada Media Group, 2010.

Jamal ma'mur Asmani, Manajemen Pengelolaan Dan Kepemimpinan Pendidikan Professional, Jogjakarta: DIVA Press, 2009. 